\title{
Analisis Kualitas dan Kadar Aflatoksin Jagung pada Pengeringan dengan Udara Alamiah
}

\section{Jefrianus Nino a}

${ }^{a}$ Fakultas Pertanian, Universitas Timor, Kefamenanu, TTU - NTT, Indonesia, email: jefrianusnino@gmail.com

\section{Article Info}

\section{Article history:}

Received 8 Agustus 2018

Received in revised form 27 September 2018 Accepted 3 Oktober 2018

DOI:

https://doi.org/10.32938/sc.v3i04.445

Keywords:

Pengeringan Udara Alamiah Aflatoksin

\section{Abstrak}

Jagung merupakan makanan pokok bagi sebagian besar penduduk di Provinsi Nusa Tenggara Timur sehingga jagung sudah tidak asing agi dan ditanam secara turun temurun. Produksi jagung yang cukup tinggi juga dapat menimbulkan masalah dalam penanganan pasca panen yakni dalam hal pengeringan. Pengeringan yang dilakukan oleh masyarakat belum terdesain dengan yang baik sehingga dapat menimbulkan penurunan kualitas dan terjadi kerusakan. Selain penurunan kualitas juga terjadi kerusakan yang disebabkan oleh kandungan air dalam biji jagung masih tinggi sehingga biji jagung diserang oleh cendawan (Aspergillus flavus) yang dapat menghasilkan aflatoksin. Tujuan penelitian ini adalah menganalisis kualitas dan kandungan aflatoksin jagung pada pengeringan dengan udara alamiah. Metode penelitian mencakup pengeringan jagung dengan tipe batch drying, analisis kadar aflatoksin dan kualitas berupa kadar karbohidrat, protein dan lemak. Pada pengeringan dengan suhu lingkungan $30^{\circ} \mathrm{C}$ dan kelembaban relatif (RH) $75 \%$ menggunakan tipe pengering batch drying tidak terjadi penurunan kadar aflatoksin maupun kualitas.

\section{Pendahuluan}

Jagung merupakan makanan pokok dan salah satu sumber karbohidrat di Provinsi Nusa Tenggara Timur (NTT) sehingga jagung sudah tidak asing lag dan ditanam secara turun temurun. Pangan pokok adalah pangan yang dikonsumsi oleh penduduk dalam jumlah yang banyak dan merupakan penyumbang energi terbesar dalam pola konsumsi pangan sumber karbohidrat (Ariani \& Pasandaran, 2005). Sebagai bahan pangan pokok, di Provinsi NTT jagung dapat dikonsumsi dalam berbagai bentuk, seperti jagung basah dengan kulit, jagung kering dengan kulit, dan jagung pipilan. Jagung basah dengan kulit dan jagung pipilan banyak dikonsumsi oleh masyarakat di NTT. Suarni \& Saenong, (2005) menyatakan perkembangan tingkat konsumsi jagung perkapita secara nasional adalah $28,98 \mathrm{~kg} / \mathrm{kapita} / \mathrm{tahun}$ (1970), turun menjadi 15,75 kg/kapita/tahun (1980), 8,48 kg/kapita/tahun (1990), 5,93 kg/kapita/tahun pada tahun 1993. Tingkat konsumsi jagung perkapita di Provinsi NTT sebesar 39,21 $\mathrm{kg} / \mathrm{kapita} / \mathrm{tahun}$. Menurut De Rosari $d k k$. (2001) menyatakan bahwa rata-rata konsumsi jagung setiap rumah tangga dalam seminggu sebesar $6 \mathrm{~kg}$ atau 1,44 $\mathrm{kg} / \mathrm{kapita} / \mathrm{minggu}$

Produksi jagung yang cukup tinggi juga dapat menimbulkan masalah dalam penanganan pasca panen (pengeringan). Pengeringan yang dilakukan oleh masyarakat belum terdesain dengan yang baik sehingga dapat menimbulkan penurunan kualitas dan terjadi kerusakan. Penurunan kualitas disebabkan oleh teknik pengeringan yang tidak tepat yakni waktu dan lama pengeringan Pemberian asap dan panas yang berlebihan pada jagung dapat menyebabkan kehilangan gula reduksi (Nino, 2014). Selain penurunan kualitas juga terjadi kerusakan yang disebabkan oleh kandungan air dalam biji jagung masih tinggi sehingga biji jagung diserang oleh cendawan (Aspergillus flavus) yang dapa menghasilkan aflatoksin. Fente $d k k$. (2001) menyatakan aflatoksin sebagai mikotoksin dengan sifat beracun dan karsinogenik tinggi yang dihasilkan dari beberapa strain Aspergillus flavus, Aspergillus parasiticus, dan Aspergillus nomius. Kapang-kapang tersebut umum dijumpai pada bahan pangan yang disimpan pada ruang penyimpanan dengan kondisi kelembaban tinggi. Spesie Aspergillus yang sering ditemukan yakni Aspergillus flavus yang memproduks aflatoksin B, dan A. parasiticus yang menghasilkan aflatoksin B dan $G$ Sedangkan aflatoksin $\mathbf{M}_{1}$ dan $\mathbf{M}_{2}$ merupakan metabolit hasil hidroksilas aflatoksin $\mathrm{B}_{1}$ dan $\mathrm{B}_{2}$ oleh sitokrom p450 $1 \mathrm{~A}_{2}$ pada manusia dan hewan yang mengkonsumsi makanan yang tercemar aflatoksin. Struktur kimia aflatoksin dapat dilihat dalam Gambar 1. Aflatoksin bersifat karsinogen dan banyak ditemukan pada produk-produk pertanian. Aflatoksin dapat menyebabkan kanker dan ginjal pada manusia bila dikonsumsi secara berlebihan.
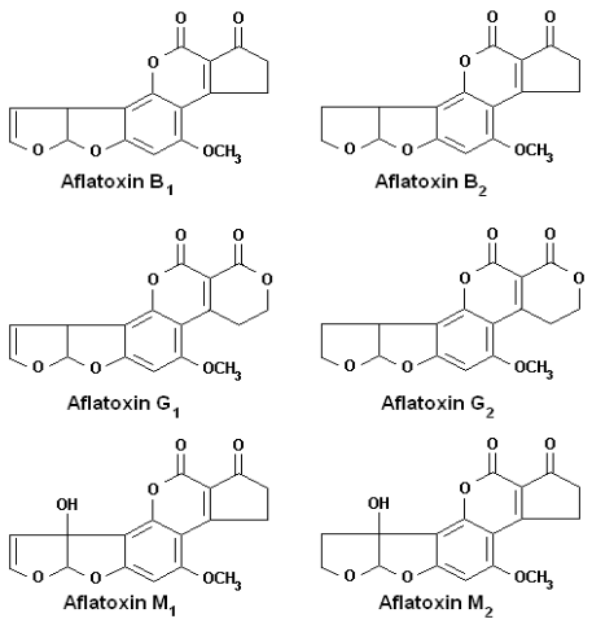

Gambar 1. Struktur Kimia Aflatoksin

Untuk itu dibutuhkan sebuah metode pengeringan dalam menentukan waktu dan lama pengeringan yang tepat agar dapat menurunkan kadar air sesuai dengan kadar air kesetimbangan sehingga tidak terjadi penurunan kualitas jagung serta kontaminasi aflatoksin. Tujuan penelitian ini yakni menganalisis kualitas dan kandungan aflatoksin jagung pada pengeringan dengan udara alamiah.

\section{Metode}

Penelitian dilakukan di Kabupaten Timor Tengah Utara, Kecamatan Kota Kefamenanu, Kelurahan Maubeli, dan dilanjutkan analisis kualitas dan aflatoksin di laboratorium Seameo Biotrop Bogor. Bahan yang diuji adalah jagung pipilan lokal putih dari Desa Manusasi, Kecamatan Miomaffo Barat. Pengujian kualitas jagung dilakukan dengan menguji kadar lemak, kadar protein, kadar karbohidrat. Sedangkan pengujian kandungan aflatoksin dilakukan pada aflatoksin B1, B1 G1, dan G2. Analisis kualitas dan kadar aflatoksin dilakukan sebanyak 2 kal yakni pada tahap awal sebelum dilakukan pengeringan dan setelah dilakukan pengeringan.

\subsection{Model Pengeringan}

Tipe pengeringan yang digunakan adalah pengeringan tumpukan (batch drying) yang berbentuk silinder. Pengeringan dilakukan dengan kapasitas $30 \mathrm{~kg}$. Udara lingkungan diambil oleh blower kemudian dialirkan ke silinder atau wadah pengering (konveksi paksa) melalui lubang inlet. Proses pengeringan dilakukan pada suhu lingkungan $30^{\circ} \mathrm{C}$ dan kelembaban relatif (RH) $75 \%$. Penampang bagian depan silinder atau wadah pengering dapat dilihat pada Gambar 2

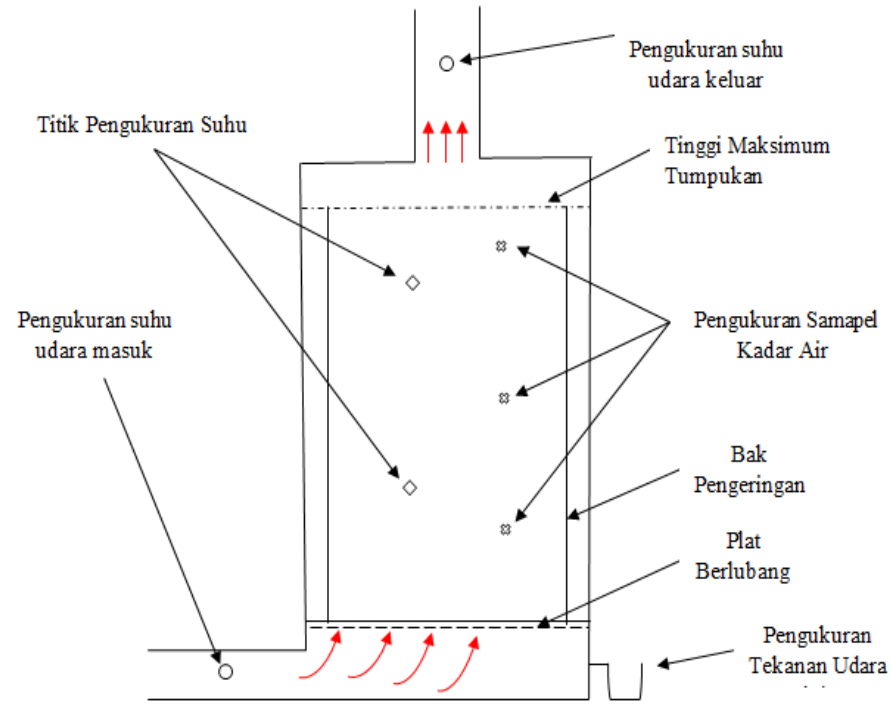

Gambar 2. Penampang Bagian Depan Silinder atau Wadah Pengering

\subsection{Tahapan Penelitian}

Tahapan-tahapan penelitian yang akan dilakukan meliputi persiapan jagung untuk proses pengeringan, persiapan alat pengeringan jagung, pengeringan, pengambilan sampel, persiapan alat analisis, identifikasi, pengamatan, perhitungan. Diagram alir analisis aflatoksin menggunakan metode TLC (Thin Layer Chromatografy) dan analisis kualitas pada pengeringan dengan udara alamiah dapat dilihat pada Gambar 3 .

\subsection{Analisis Kadar Aflatoksin B1, B2, G1, G2}

Analisis kadar aflatoksin B1, B2, G1, G2 dilakukan sebanyak 2 kali yakni, kondisi awal sebelum dilakukan pengeringan dan sesudah pengeringan. Pada tahap sebelum pengeringan, analisis kadar aflatoksin dilakukan pada tahap awa sebelum dilakukan pengeringan (sampel jagung tanpa pengeringan) dengan kadar air awal $33 \%$ bb. Sampel yang dibutuhkan dalam analisis sebanyak 3 sampel dengan berat masing-masing sampel sebanyak 50 gram. 


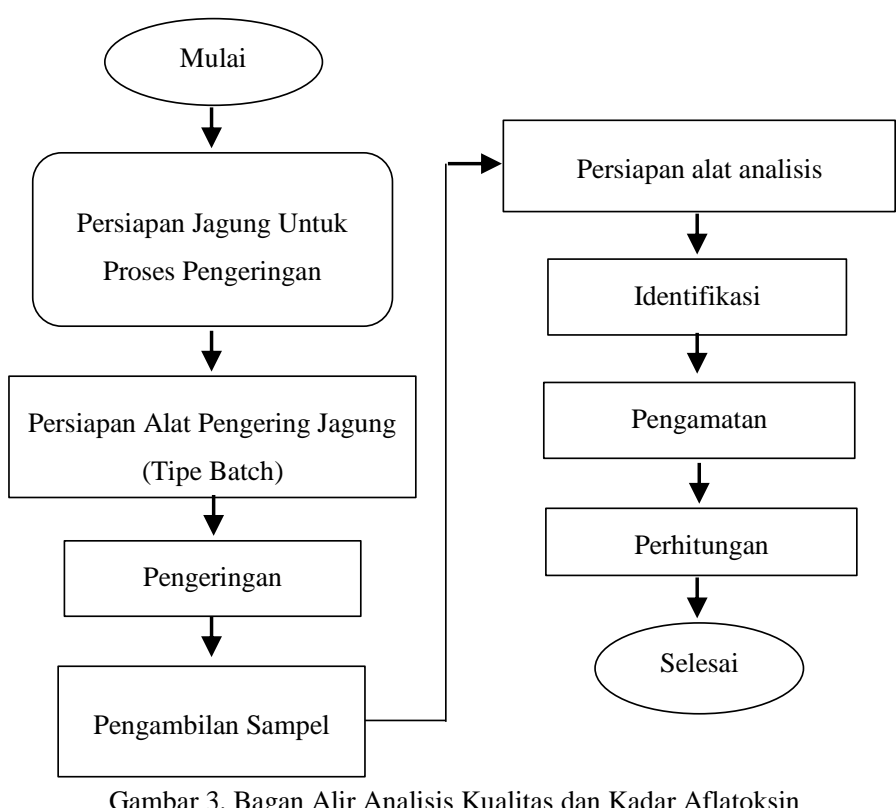

Gambar 3. Bagan Alir Analisis Kualitas dan Kadar Aflatoksin

Pada tahap setelah pengeringan, analisis kadar aflatoksin dilakukan setelah sampel jagung dilakukan pengeringan dengan kadar air akhir $16 \%$ bb Pengeringan dilakukan dengan perlakuan laju aliran udara dan lama pengeringan yang berbeda-beda. Variabel laju aliran udara yang digunakan yakni $0.025 \mathrm{~m}^{3} / \mathrm{s}$ setara dengan $0.83 \mathrm{~L} / \mathrm{s}-\mathrm{kg}, 0.020 \mathrm{~m}^{3} / \mathrm{s}$ setara dengan $0.67 \mathrm{~L} / \mathrm{s}-\mathrm{kg}$ sedangkan 0.015 $\mathrm{m}^{3} / \mathrm{s}$ setara dengan $0.5 \mathrm{~L} / \mathrm{s}-\mathrm{kg}$ dan perlakuan lama pengeringan 8 jam $(08.00$ 16.00 Wita), 6 jam (90.00-15.00 Wita dan 4 jam (10.00-14.00 Wita). Analisis aflatoksin dilakukan dengan metode TLC (Thin Layer Chromatografy). Prinsip dasar TLC adalah penempatan sampel uji pada fase stasioner yang berupa lempeng tipis dan sampel akan bergerak sampai batas tertentu dengan bantuan fase gerak karena adanya gaya kapiler. Tahapan Cara Kerja Analisis Kadar Aflatoksin adalah sebagai berikut:

a. Persiapan

Persiapan dilakukan dengan penjenuhan bejana TLC dengan fase gerak (kloroform:aseton $=9: 1$ ). Persiapan lempeng TLC dilakukan dengan mendiamkan lempeng TLC dalam oven dengan suhu $80^{\circ} \mathrm{C}$ selama satu jam b. Identifikasi

Analisis aflatoksin dilakukan dengan menggunakan Thin Layer Chromatography $($ TLC) satu dimensi dengan fase gerak (kloroform: aseton = 9:1). Plat TLC yang digunakan adalah plat dengan fase diam silika gel. Ekstrak aflatoksin yang telah dihasilkan kemudian ditotolkan secara kuantitatif pada lempeng kromatografi. Setelah itu lempeng kromatografi dimasukkan ke dalam bejana yang berisi pelarut (kloroform: aseton $=9: 1$ ) yang telah dijenuhkan lalu dielusi dari bawah ke atas sampai pelarut mencapai batas elusi. Lempeng kromatografi kemudian dikeringkan

c. Pengamatan

Hasil elusi dikeringkan dan diamati di bawah lampu UV pada panjang gelombang $365 \mathrm{~nm}$. Perpendaran dan waktu rambatnya (Rf) dari bercak sampel dan standar dibandingkan.

d. Perhitungan

Kandungan aflatoksin pada sampel didapatkan dengan membandingkan intensitas perpendarannya dengan standar. Hal tersebut didapatkan dari deret standar aflatoksin yang dielusi dengan pelarut. Aflatoksin dikatakan positif apabila Rf sampel sama dengan standar. Kandungan aflatoksin ditentukan dengan sesuai rumus Bainton $d k k$. (1980).

\subsection{Analisis Kadar Lemak}

Analisis kadar lemak dilakukan sebanyak 2 kali yakni, kondisi awal sebelum dilakukan pengeringan dan sesudah dengan berat sampel 50 gram. Analisis kadar lemak dilakukan dengan metode Soxhlet. Tahapan cara analisis kadar lemak adalah sebagai berikut:

a. Mengeringkan labu lemak yang akan digunakan dalam oven pada suhu $105^{\circ} \mathrm{C}$ selama 1 jam.

b. Didinginkan dalam desikator selam 15 menit kemudian ditimbang beratnya beserta beberapa labu didih di dalamnya.

c. Sampel yang telah dihaluskan ditimbang sebanyak 50 gram lalu ditempatkan pada kertas pembungkus.

d. Sampel yang telah dibungkus kemudian dimasukkan ke dalam alat ekstraksi yang telah dipasang bersama labu yang telah berisi pelarut heksana dan direfluks selama 2-3 jam kemudian dilanjutkan dengan proses destilasi untuk memisahkan pelarut heksana.

e. Labu berisi lemak kemudian dikeringkan di dalam oven bersuhu $105^{\circ} \mathrm{C}$ selama 1 jam dan didinginkan di dalam desikator selama 15 meni kemudian ditimbang dan catat beratnya. Untuk menghitung kadar lemak digunakan persamaan AOAC, (1995).

\subsection{Analisis Kadar Protein}

Analisis kadar Protein dilakukan sebanyak 2 kali yakni, kondisi awal sebelum dilakukan pengeringan dan sesudah dengan berat sampel 50 gram. Analisis kadar protein dilakukan dengan metode Kjeldahl. Tahapan cara analisis kadar protein adalah sebagai berikut:

a. Menimbang sampel sebanyak 50 gram dan dimasukkan ke dalam labu dekstruksi.

b. Selanjutnya ditambahkan 10 gram selenium dan $12 \mathrm{ml} \mathrm{H}_{2} \mathrm{SO}_{4}$ pekat.

c. Sampel didekstruksi dengan alat dekstruksi pada suhu $400^{\circ} \mathrm{C}$ selama 1 jam.

d. Sampel didinginkan dan dipindahkan ke dalam labu takar. lalu ditambahkan aquades sampai volume menjadi $100 \mathrm{ml}$. Sebanyak $10 \mathrm{ml}$ sampel dari labu takar diambil dan dimasukkan ke dalam labu destilasi.

e. Kemudian ditambahkan $\mathrm{H}_{3} \mathrm{BO}_{4} 4 \%$ sebanyak $25 \mathrm{ml}$ ke dalam labu takar berisi sampel dan ke dalam erlenmeyer serta diteteskan indikator ke dalam masing-masing labu, kemudian dipasang pada alat destilasi.

f. Proses destilasi dilakukan dengan menggunakan $\mathrm{NaOH} 40 \%$. Hasil destilasi kemudian dititrasi dengan larutan $\mathrm{HCl} 0.0968 \mathrm{~N}$. Untuk menghitung kadar protein digunakan persamaan AOAC, (1995).

\subsection{Analisis Kadar Karbohidrat}

Analisis kadar karbohidrat dilakukan sebanyak 2 kali yakni, kondisi awal sebelum dilakukan pengeringan dan sesudah dengan berat sampel 50 gram. Untuk menghitung kadar karbohidrat digunakan persamaan AOAC, (1995).

\section{Hasil dan Pembahasan}

\subsection{Analisis Aflatoksin}

Tabel 1. menunjukkan data perbandingan kandungan kadar aflatoksin pengeringan dengan menggunakan pengering tipe tumpukan (batch drying) dengan kualitas menurut standar SNI. Berdasarkan hasil analisis terlihat bahwa pengeringan menggunakan tipe pengering batch drying dengan memanfaatkan udara alamiah tidak terjadi kontaminasi aflatoksin. Hasil pengujian diperoleh kadar aflatoksin B1, B2, G1 dan G2 secara berturut-turut adalah B1 sebesar 1.98 $\mu / \mathrm{kg}(1.98 \mathrm{ppb})$, B2 sebesar $2 \mu / \mathrm{kg}$ (2 ppb), G1 sebesar $1.08 \mu / \mathrm{kg}$ (1.08 ppb) dan G2 sebesar $1.5 \mu / \mathrm{kg}(1.5 \mathrm{ppb})$. Kontaminasi maksimum aflatoksin yang dipersyaratkan oleh SNI untuk pangan maupun pakan adalah $50 \mathrm{ppb}$. Kondisi iklim di Kabupaten Timor Tengah Utara dengan suhu udara lingkungan mencapai $34^{\circ} \mathrm{C}$, namun kelembaban relatif udara yang cukup tinggi sebesar $89 \%$ sangat mendukung pembentukan senyawa aflatoksin oleh kapang jenis Aspergilus flavus yang sering mencemari komoditas jagung sehingga perlu adanya penanganan dengan cara pengeringan lebih intensif. Faktor terpenting yang mempengaruhi tingkat cemaran dan pertumbuhan Aspergilus flavus adalah faktor kelembaban relatif lingkungan selama penyimpanan dan lamanya penyimpanan (Kusumaningrum $d k k$. 2010).

\begin{tabular}{|c|c|c|c|}
\hline \multirow{2}{*}{ No } & $\begin{array}{l}\text { Aflatoksin } \\
(\mathrm{ppb})\end{array}$ & \multirow{2}{*}{$\begin{array}{c}\text { Persyaratan } \\
\text { Mutu SNI } \\
(\mathrm{ppb})\end{array}$} & $\begin{array}{c}\text { Hasil Uji Laboratorium Kadar } \\
\text { Aflatoksin (ppb) }\end{array}$ \\
\hline & $\begin{array}{c}\text { Jenis } \\
\text { Aflatoksin }\end{array}$ & & Pengering Tipe Bed \\
\hline 1 & B1 & 50 & 1.98 \\
\hline 2 & B2 & 50 & 2 \\
\hline 3 & G1 & 50 & 1.08 \\
\hline 4 & G2 & 50 & 1.5 \\
\hline
\end{tabular}

Menurut Yunus $d k k$. (2011) menyatakan bahwa faktor utama dalam pembentukan aflatoksin yang dihasilkan oleh kapang Aspergillus $s p$ adalah suhu $5-45^{\circ} \mathrm{C}$ dan kelembaban relatif (RH) minimum sebesar $80 \%$. Sementara itu BPOM mengatur ambang maksimum aflatoksin B1 pada jagung untuk konsumsi manusia sebesar $20 \mathrm{ppb}$ dan total aflatoksin $35 \mathrm{ppb}$. Dengan demikian jagung yang telah dikeringkan menggunakan pengering tipe tumpukan (batch drying) sangat baik untuk direkomendasikan untuk pangan maupun pakan.

\subsection{Analisis Kualitas}

Tabel 2. menunjukkan data perbandingan kualitas jagung pada pengeringan dengan menggunakan pengering tipe tumpukan (batch drying) dengan kualitas menurut standar SNI. Berdasarkan hasil analisis terlihat bahwa pengeringan menggunakan tipe pengering batch drying dengan memanfaatkan udara alamiah tidak terjadi penurunan kualitas baik karbohidrat, protein dan lemak. Hal ini dikarenakan proses pengeringan dilakukan dengan metode yang tepat. Menurut Susanto \& Saneto (1994) pengaruh pengeringan terhadap mutu dan kualitas bahan atau produk tergantung pada perlakuan pendahuluan, lama pengeringan, jenis proses pengeringan, dan jenis bahan yang dikeringkan. Tujuan pengeringan adalah untuk mengurangi kadar air pada bahan sampai pada batas tertentu dimana perkembangan mikroorganisme seperti bakteri, khamir atau kapang yang dapat menyebabkan pembusukan dapat dihentikan sehingga kualitas bahan dapat dipertahankan dan dapat disimpan lebih lama (Suismono, 2001).

Berdasarkan Tabel 2. perlakuan metode pengeringan dari percobaan tersebut tidak mengakibatkan penurunan mutu atau kualitas jagung sehingga tetap stabil dan bahkan nilainya cenderung lebih tinggi SNI jagung untuk pangan 
dan pakan dengan nilai maksimal kadar protein 9.05\%, kadar karbohidrat $74.99 \%$, sedangkan kadar lemak $3.74 \%$.

Tabel 2. Hasil Analisis Perbandingan Mutu atau Kualitas Jagung Pipilan

\begin{tabular}{clcc}
\hline \multirow{2}{*}{ No } & \multirow{2}{*}{ Jenis Pengujian } & $\begin{array}{c}\text { Persyaratan } \\
\text { Mutu SNI (ppb) }\end{array}$ & $\begin{array}{c}\text { Hasil Uji Laboratorium } \\
\text { Pengering Tipe Bed (Batch Drying) }\end{array}$ \\
\hline 1 & Kadar Protein (\%) & 7.5 & 9.05 \\
2 & Karbohidrat (\%) & 72 & 74.99 \\
3 & Kadar Lemak (\%) & 3.0 & 3.74 \\
\hline
\end{tabular}

\section{Simpulan}

Hasil analisis aflatoksin dan kualitas pada lama pengeringan 8 jam/hari tidak terjadi kontaminasi aflatoksin dan pengurangan kualitas. Nilai hasil analisis aflatoksin sangat kecil dari nilai standar aflatoksin SNI. Hasil analisis mutu atau kualitas jagung juga memiliki nilai yang cenderung lebih tinggi SNI jagung untuk pangan maupun pakan.

\section{Pustaka}

Ariani, M. dan E. Pasandaran. 2005. Pola Konsumsi dalan Permitnaan Jagung untuk Pangan. Ekonomi Jagung Indoensia. Badan Penelitian dan Pengembangan Pertanian departemen Pertanian.

AOAC. 1995. Official Methods of Analysis of The Association Analytical Chemist, Inc, Washington D.C.

Bainton SJ, Coker RD, Jones BD, Morley EM, Nagler MJ, Turnel RL. 1980. Mycotoxin Training Manual; Tropical Product Institute, London p. 1-176.

de Rosari. B, B., Don Bosko Meke, dan A. Bamualim. 2001. Manajemen Pasca Panen jagung di Nusa Tenggara Timur. Laporan hasil Penelitian BPTP NTT.

Fente CA, Ordaz J Jaimez, Vazquez BI, Franco CM, Cepeda A. 2001. New additive for culture media for rapid identification of aflatoxin-producing Aspergillus strain. Appl. Environ. Microbiol. 67(10): 4858-4862.

Kusumaningrum HD. Suliantari D T. Aris H P Sindhu. S.U Aldilla. 2010 Cemaran Aspergillus flavus dan aflatoksin pada rantai distribusi produk pangan berbasis jagung dan faktor.

Nino J. 2014. Pengaruh Model Penyimpanan Jagung (Zea Mays, L) Tehadap Pertumbuhan dan Hasil. [Skripsi], Kefamenanu: Fakultas Pertanian, Universitas Timor.

Suarni dan M. Sudjak Saenong, 2005. Perbaikan Gizi Masyarakat dan Diversifikasi Pangan Melalui Pemasyarakatan Nasi Jagung sebagai salah satu Alternatif Penangan Busung Lapar. Prosiding Seminar Nasional Pemasyarakatan Inovasi Teknologi Dalam Upaya Mempercepa Revalitasi Pertanian dan Pedesaan di Lahan Marginal. Pusat Analisis Sosial Ekonomi.

Suismono. 2001. Teknologi Pembuatan Tepung dan Pati Umbi-Umbian Untuk Menunjang Ketahanan Pangan. Majalah Pangan Media Komunikasi dan Informasi 37 (10); 37-94.

Susanto.T, B. Saneto. 1994. Teknologi Pengolahan Hasil Pertanian. Bina Ilmu. Surabaya.

Yunus AW, E. Razzazi-Fazeli, J. Bohm. 2011. Aflatoxin B1 in affecting broiler's performance, immunity, and gastrointestinal tract: A review of history and contemporary issues. J.Toxins 3: 566-590. 